\title{
FIRMS' ATTRIBUTES AND ENVIRONMENTAL DISCLOSURE: EVIDENCE FROM LISTED FIRMS IN BANGLADESH
}

\author{
MD. ALI ARSHAD CHOWDHURY ${ }^{1}$ \\ MOURI DEY 1 \\ MD. THASINUL ABEDIN1,*
}

Received: 3September 2019 / Revised: 7November 2019,17January 2020 / Accepted: 22January 2020 (C) 2020 Faculty of Business and Accountancy, University of Malaya. All rights reserved.

\begin{abstract}
A B S T R A C T
Research aim: This paper aims at finding out the quality of environmental reporting and its association with company characteristics considering listed companies from various sectors through the lens of legitimacy theory and stakeholder theory in Bangladesh.

Design/ Methodology/ Approach: Secondary data relevant to company characteristics and environmental disclosure have been collected from various parts of the annual reports of firms for the year 2016. This study considers one dependent variable breaking down into three levels and four independent variables. Level of environmental disclosure (LED) is the dependent variable while size, profitability, leverage and industry type are independent variables.

Research finding: By employing Ordinary Least Square (OLS), the level of environmental disclosures $(L E D-1)$ is significantly associated with firm size, unlike the profitability, leverage and production attributes. The moderate disclosure level (LED-2) is likely to be affected by the firm size, unlike the other factors. Furthermore, the greatest disclosure level (LED-3) is to be strongly affected by business size and profitability. Moreover, the study confirms that firm type has no impact on environmental disclosure.

Theoretical contribution/ Originality: This paper provides insights into the quality of environmental disclosure of Bangladeshi companies. It reveals that only leverage and size affect the total environmental disclosure of firms, unlike type and other features. This has a perfect alignment with the legitimacy theory that larger firms tend to disclose more to legitimise their activities and scale up their image.

Practitioner/ Policy implication: This paper helps firms in implementing environmental disclosure policies and make them more environmentally responsible.

Limitation/ Implication: Exploring the qualitative environmental disclosures among various types of industries in Bangladesh in a longitudinal manner by addressing more control variables may contribute to future research on determinants of corporate environmental reporting.

Keywords: Environmental Disclosure, Company Characteristics, Bangladesh

Type of article: Research Paper

JEL Classification: C01, C21
\end{abstract}

\section{Introduction}

The protection of the environment has become an unavoidable circumstance in industrial activity. Due to legislation, some firms have adopted a reactive strategy to reduce environmental impacts. Others have preferred more proactive strategies introducing voluntarily practices focused on reducing their environmental impact because civilisation is now being criticised for

\footnotetext{
* Corresponding author. ${ }^{1}$ Department of Accounting, University of Chittagong, 4331, Bangladesh. Email: Chowdhury, M.A.A. (arshad@cu.ac.bd), Dey, M. (mouridey@cu.ac.bd), Abedin, M.T. (abedin@cu.ac.bd).
} 
interrupting the natural settings, biodiversity and survival of living creatures, natural resources (renewable and non-renewable) and community. Firms are ostentatiously responsible for environmental degradation through the manufacturing and releasing of harmful materials, fluids, sounds, and emissions of carbon (Gani \& Shrama, 2009). Uncontrolled and illegal business practices and pollution generating activities have delivered tremendous negative effect mostly on the vulnerable and marginal people living in the society. Business must accept its responsibilities to the society and environment and meet the challenge of accommodating new business realities into its practices towards sustainable development.

Like other countries, environmental awareness in Bangladesh is increasing day by day. Regulations like the 'Environment Conservation Act, 1995', Environmental Pollution Control Ordinance, 1977, National Environmental Policy, 1992, Environmental Conservation Rules, 1997, Environment Court Act, 2010 (Noman \& Akter, 2010) regarding environmentalism legislate a green agenda. In addition, the Department of Environment (DoE) set Environmental Quality Standards for reporting purposes for different industries such as fertiliser factories; integrated textile mill and large processing units; pulp and paper factories; cement factories; industrial boilers; nitric acid plants; distilleries; sugar production; leather tanneries; food processing and oil refineries in Bangladesh in 2001. Along with these, the DoE established Environment Impact Assessment guidelines for industry. Furthermore, many NGOs like the International Union for the Conservation of Nature (IUCN), National EIA Association, International Centre for Living Aquatic Resources Management (ICLARM), Bangladesh Centre for Advanced Studies (BCAS), Surface Water Modelling Centre (SWMC), Environment and GIS Support for Water Sector Planning Project (EGIS), Local Government Engineering Department (LGED), the Bangladesh Environmental Lawyers Association (BELA), Bangladesh AgroProcessors' Association (BAPA), Ain o Salish Kendra (ASK), Bangladesh Legal Aid and Services Trust (BLAST), and Bangladesh National Woman Layers Association (BNWLA) put tremendous pressure on the private sector to take initiatives to conserve the environment and ecology in Bangladesh. At present, about 200 laws prevailing in this territory bear the impact of the environmental conservation directly, indirectly or causally. In addition, Bangladesh is a signatory of as many as 44 international conventions, treaties and protocols in connection with the protection of environment and ecology (Hossan, 2014). Under these circumstances, businesses are legally restricted to abide by the law. In addition, it cannot avoid its commitment to society at large.

Stakeholder theory suggests that organisation make decisions for the interests of stakeholders (Freeman, Harrison, \&Wicks, 2007). It considers both the internal and external stakeholders of the organisation. Generally, the demands of stakeholders are informed by the reporting in the form of the annual report. The growing awareness and pressure from the various stakeholders on the natural environment force firms to disclose their environmental performances. The Securities and Exchange Commission (SEC), the monitoring and controlling authority of the stock exchanges in Bangladesh, has taken necessary steps to promulgate a sustainability reporting framework to establish uniform, timely, 
relevant and comparable disclosures of the listed companies in Bangladesh. Stakeholders of the companies are gradually becoming aware of corporate operations (Sobhani, Amran, \& Zainuddin, 2009). These socio-political and organisational changes might influence the social responsibilities of the corporate bodies (Belal, 2000; Hossain, Islam, \& Andrew, 2006) that might ultimately be reflected in the disclosure practices of the listed companies (Sobhani et al., 2009).Thus, at present, firms disclose environmental information separately or as a part of the annual report. In this regard, several questions could be raised. For example, (i) Do all the firms disclose environmental information? (ii) What kind of information do firms disclose? (iii) Is this information objectively disclosed? (iv) Is this information reflective of their environmental performance? (v) Which firms disclose more environmental information?

To resolve the above-mentioned questions, the environmental performance of listed firms from various sectors has been explored. We also examine the nature of this information. In addition, this paper examines the firm-specific factors influencing environmental performance. Based on the findings, we propose a framework for environmental reporting that meets the stakeholders' demands.

\section{Literature Review}

The merits of environmental reporting are manifold. Cormier, Magnan, and Velthoven (2005) asserted the importance of quality environmental disclosures that may be helpful for investors in assessing environmental risk exposure, making proper judgements(Deegan,2004) and revising the investment strategy of the foreign investors (Mashayekhi \& Mashayekh, 2008; Cormier, Magnan, \& Valthoven, 2005). It is also a mechanism and a way to show the environmentfriendly practices of companies (Al-Tuwaijri, Christensen, \& Hughes, 2004; Clarkson, Richardson, \& Vasvari, 2008). Disclosure of environmental information forecasts financial and reputational benefits. Sometimes, managers advocate sustainability to provide comprehensive and significant information about companies' environmental performance (Dias-Sardinha, Reijnders, \& Antunes, 2007). Furthermore, Holt (1998) confirms that environmental performances are not merely to save the environment. Firms perform environmental activities in order to cut costs, improve efficiency and the company's image and reduce insurance premiums. These facts eventually motivate firms to report their environmental performances to gain competitive advantage. In addition, unlike poor environmental performers, better environmental performers will connect with the existing stakeholders using verifiable information ( $\mathrm{Li}$, Richardson, \& Thornton, 1997; Verrecchia, 1983).Worldwide, the volume of environmental reporting is increasing over time since companies are paying attention to the level of disclosure (Eljayash, James, \& Kong, 2012).

A signal of transparency and managers' reputation and social profile would be achieved through more environmental disclosures (Deegan, Cooper, \& Shelly, 2006; Patel, Balic, \& Bwakira, 2002; Simnett, Vanstraelen, \& Chua, 2009). Among various motivating factors, legal obligations are one of the most important for environmental reporting (Wilmshurst \& Frost, 2000). Corporate bodies disclose such information to legitimise their business activities. In other words, they 
display such information to show that they abide by regulation and standards and avoid negative publicity and manage compliance costs (Cho \& Patten, 2007). Due to legislation, some firms have adopted a reactive strategy to reduce environmental impacts. Many researchers have tracked the effect of enforced legislation and regulations on firms' environmental practices (Delmas, 2002; Majumdar \& Marcus, 2001). Delmas (2002) concluded that the government has an influence on firms' decision-making regarding environmental standard adaptation, and it can reduce the search costs of adopters by providing technical assistance. Firms' internal characteristics are also well-connected to their' environmental performance (McGuinness, Vieito, \& Wang, 2017).

After enforcing environmental conservation acts and rules, firms started to disclose environmental information. Environmental disclosures are still nascent in Bangladesh. Environmentally exposed operations, previous legal environmental engagements, media exposure, environmental problems and risks, and previous engagements with environmental groups are contained in these disclosures (Clarkson, et al., 2008; Marshall, Brown, \& Plumlee, 2007). Belal (1997) surveyed the current scenario of environmental disclosure in Bangladeshi firms. This survey reveals that out of 50 firms, only three reported environmental information in their annual reports. This paper also outlines that only positive disclosures were made; there were no negative disclosures, and disclosures are descriptive. All disclosures were made in the chairman statement or the managing director report. Imam (2000) carried out a study of Corporate Social Responsibility (CSR) practices and found that only nine firms out of 40 reported environmental issues confined to protecting the environment through controlling pollution and planting of trees.

Similarly, Shil and Iqbal (2005) researched the companies' environmental disclosure analysing 117 annual reports of different Bangladeshi organisations. Among the 117, only 13 companies disclosed descriptive environmental information. However, Hossain et al. (2006) found that CSED (corporate social and environmental disclosure) is associated with the nature of the company (Industry), presence of debentures in the annual report (Debenture) and net profit margin. Bose (2012) found that the nature of environmental information was qualitative, not quantitative after inspecting the reporting status of 11 companies operating under Petrobangla, engaged in oil and gas exploration, production, transmission, distribution, conversion and development and marketing of coal and hard rock. Lack of legal requirements, lack of resources, lack of knowledge, poor performance and bad publicity are the main reasons for qualitative information (Rahman \& Muttakin, 2005). Ahmad (2012) analysed the environmental disclosure practices of 40 listed companies of Dhaka Stock Exchange (DSE). The satisfactory disclosure items were maintained by the pharmaceuticals industry, and every sample company disclosed mandatory disclosure requirements of energy expenditure. Other sectors and the other environment-related reporting practices were very poor, and the available voluntary information was qualitative and positive.

Sobhani, Amran, \& Zainuddin (2012) inspected the environmental reporting of the banking sector and found that the disclosure in the annual reports is relatively higher than that of the banks' website. Hence it is evident that most of 
the disclosures are reported through printed media in the banking sector. This might occur due to short of internet access for the local stakeholders. The study also revealed that all listed banks disclose sustainability in annual reports and corporate websites in a somewhat hidden manner. In the sustainability disclosure, disclosure of the social dimension is higher than that of the economic and environmental dimensions. However, disclosure of environmental information is grossly avoided by all listed banks. The pattern of disclosure is similar in terms of different generations and systems of the banks. As the study aimed at providing a general view of practices concerning corporate sustainability disclosure (CSD) issues in the annual reports and websites of all listed banks, it cannot present an in-depth analysis on a single bank. This paper sets the requisite for further extensive research on several individual banks to explore the trend, process, and managerial insights to CSD.

The above literature confirms that different researchers considered different sectors at different times. Although the results are more or less the same, the effort to address the issue is gradually increasing. Global issues like climate change, global warming, carbon emission, etc. create awareness among the general public and, as a global partner, Bangladesh is also playing a vital role in reducing pollution. As an inseparable part of society, business firms are also expected to contribute to conserving nature by performing environmental actions. This motivates researchers to know about the present scenario of environmental reporting of various business firms though environmental reporting quality has not been universally acclaimed as it is challenged with accuracy and transparency (Kolk, 2006). In addition, non-financial disclosure has been criticised for lack of relevance and credibility (Michelon, Pilonato, \& Ricceri, 2015).Moreover, prior research has not been successful in providing an accurate measure of environmental disclosure quality due to the lack of convincing theoretical underpinning and the subjectivity that surround the developed proxies (Baalouch, Ayadi, \& Hussainey, 2019).Thus, to fill this gap, we focus on the quality of environmental disclosure and factors that may influence such reporting. We categorised the environmental information on the basis of its identified proximity to performance disclosed in the annual reports.

\subsection{Theoretical Framework}

This paper solely stands on the legitimacy theory and stakeholder theory. Legitimacy theory mandates an organisation's behaviour in adopting social responsibility practices consistent with the organisation's norms and values. It articulates that as an entity of the society to give legal force and a mandate to act, organisations must perform some social responsibilities (Burlea \& Popa, 2013; Suchman, 1995) under a social contract. The environmental performance of firms underlies this social contract. The central tenet of this theory stands on a belief that a firm's activities are affected by the society in which it runs. Influenced by society, a firm's operation is similar to a social contract looking forward to maintaining social credibility and acceptability (Lada \& Kozarkiewicz, 2014).

Environmental legitimacy affects the carbon disclosure through the process of green innovation ( $\mathrm{Li}$, Huang, Ren, Chen, \& Ning, 2018). Legitimising the activities from the dimension of a socially responsible firm allows a firm act on 
its justified premises. Ensuring the legitimacy of activities is deemed to have a reasonable impact on its external environment. Legitimacy has attained considerable attention in social accounting research that has contributed to unearthing the motives and incentives that drive firms to involve in environmental disclosures (Patten, 1991; Brown \& Deegan, 1998; Wilmshurst \& Frost, 2000; O'Donovan, 2002; Deegan, Rankin, \& Tobin, 2002; Deegan, 2007; Archel, Husillos, Larrinaga, \& Spence, 2009).

Stakeholder theory (Ullmann, 1985) is used to explain the level of corporate social responsibility performed by the firms. Environmental disclosure is denoted as a wider category of corporate social responsibility disclosures (Adams, Hill, \& Roberts 1998; Neu, Warsame, \& Pedwell, 1998). The fundamental tenet of stakeholder theory is that a firm would be successful at that time when it can manage all the relationships it has with the stakeholders. Clarkson (1995) stated that firms and their managers manage relationships with the stakeholders and disclosing environmental information as required by stakeholders. To explain social responsibility disclosures, both legitimacy theory and stakeholder theory expect that the firms use such disclosures as a means of legitimising their operations.

Only a few studies could be found in environmental disclosure based on legitimacy and stakeholder theory in the Bangladesh context. For example, in a study of Islam and Deegan (2008), a combination of legitimacy theory, stakeholder theory, and institutional theory was used to explore motivations behind corporate social and environmental reporting practices in textile industries of Bangladesh (Islam \& Deegan, 2008). This study considered textiles only. In this present paper, the motive of all firms to disclose environmental performance is explored.

\subsection{Company Characteristics and Environmental Reporting}

Three decades ago, the environmental performance of US firms was qualitative (Wiseman, 1982). It has been revealed that positive environmental disclosures significantly outperformed the average amount of negative disclosures of 197 sample firms from 50 industries of Australia. Furthermore, positive environmental disclosures are reported by environmentally exposed firms (Deegan \& Gordon, 1996).

Deegan and Rankin (1996) found that accused firms disclosed more positive environmental information than the same type of firms that have not been accused of environmental mismanagement. In the absence of disclosure regulations pertaining to environmental issues, those firms only provided environmental information which was favourable to their corporate image.

Upon studying regulations for environmental disclosure for Australian firms, Frost (2007) found a significant increase in the recognition of environmental regulation within the statutory sections. The findings outlined that in reporting negative information, the provision has been effective. As a result, the introduction of the new provision has increased the transparency of corporate performance. Zeng, Xu, Dong, and Tam (2010) analysed environmental information disclosure (EID) for 871 Chinese firms. The results revealed a negative association between the marketisation level and corporate EID. The 
study reveals that environment-sensitive sectors have high levels of corporate EID, including papermaking and printing, metal, non-metal mining, and food \& drink, and large firms.

De Villiers and Van Staden (2010) proved that environmental information disclosure depends on an individual's characteristics. Female respondents are more positive regarding environmental information disclosure. Moreover, the proportion and age of the female directors have a positive impact on the overall environmental performance of the organisations (Elmagrhi, Ntim, Elamer, \& Zhang, 2019).A meta-analysis showed that company size and ownership concentration are significantly and positively associated with CSD, while age, profitability and leverage indicate an insignificant positive association(Majumder et al., 2019). Environmental disclosure is positively linked to environmental performance. Company attributes, such as large size, the need for capital, profitability and capital spending significantly affect environmental disclosure quality (Iatridis, 2013).

The above discussion confirms that internal and external motivating factors affect environmental disclosures. External groups are regulatory bodies, customers, suppliers, investors, etc., while internal factors are company's features such as size, industry type, profitability level, etc. This paper concentrates only on the impact of internal factors on environmental performance. A summary of the firm's internal factors of corporate environmental disclosures is given below.

Table 1. Internal Factors responsible for environmental reporting

\begin{tabular}{ll}
\hline Internal Factors & Suggested Literature \\
\hline Business size & Hackston and Milne (1996); Brammer and Pavelin (2008); Said, \\
& Zainuddin, and Haron (2009); Arussi, Selamat, and Hanefah (2009); \\
& Akbas (2014); Dibia and Onwuchekwa (2015); Al-Gamrh and AL-Dhamari \\
& (2016); Ebiringa, Yadirichukwu, Chigbu, and Ogochukwu (2013); Jariya \\
& (2015); Hossain et al. (2006) \\
Industry Type & Hackston and Milne (1996); Akbas(2014) \\
Profitability & Said et al. (2009); Akbas (2014); Al-Tuwaijri et al. (2004); Dibia and \\
& Onwuchekwa (2015); Ebiringa et al.(2013); Jariya (2015); Joshi, Suwaidan, \\
& and Kumar (2011) \\
Leverage & Mitali, Kuhali et al. (2000); Brammer and Pavelin (2008); Setyorini and \\
& Ishak (2012); Dibia and Onwuchekwa (2015); Joshi et al. (2011) \\
\hline
\end{tabular}

\subsection{Hypotheses Development}

\subsubsection{Company Size and Environmental Disclosure}

Firm size has a positive influence on environmental disclosure (Patten, 1991; Freedman \& Jaggi, 2005; Brammer \& Pavelin, 2008). Large firms are likely to disclose more environmental information than small firms (Hackston \& Milne, 1996; Said et al., 2009; Michelon \& Parbonetti, 2012)as they have sufficient funds to invest in voluntary environmental performances. However, a few researchers claim that there is an adverse association between firm size and environmental disclosure (Ebiringa et al., 2013; Jariya, 2015). According to stakeholder theory, international customers and media are the most powerful stakeholders for Bangladeshi textiles and corporate social environmental disclosure of these companies are influenced by the customers' demand since international 
customers rely on annual reports for this information (Islam \& Deegan, 2008). Moreover, big firms that operate through branches and plants can obtain benefits by providing additional information concerning their influence on the areas in which they operate, such as their impact on the environment and the economic activity, to obtain a "social and general appreciation" of their activity (Bansal \& Clelland, 2004; Hasseldine, Salama, \& Toms, 2005). Finally, legitimacy theory suggests that big firms must satisfy the social expectations of a large range of stakeholders, and for this reason, they need to produce more information (Schipper, 1991). As this study considers all types of companies, larger company's social obligation and accountability will be more than smaller ones because large companies produce more products with more wastages, emissions, pollutants, etc. Consumers, civil society, NGOs, etc. expect more actions to save the planet from larger companies. Thus, this paper expects that large companies disclose more environmental information at a higher quality.

H1: There is a significant relationship between company size and environmental disclosure level.

\subsubsection{Firm Type and Environmental Disclosure}

Business type is a determinant in environmental disclosure (Deegan \& Gordon, 1996). According to stakeholder theory, a sector's characteristics influence the quality of the information produced. This quality partly depends on the level of environmental sensitivity of stakeholders (Sinclair-Desgagné \& Gozlan, 2003). In particular, firms operating in environmentally sensitive sectors and having a high environmental impact (Cowen, Ferreri, \& Parker, 1987; Salama, Anderson, \& Toms, 2011) tend to produce more environmental information (Brammer \& Pavelin, 2008).Therefore, industry type is a significant factor associated with environmental disclosure in the annual report (Hackston \& Milne, 1996; Halme $\&$ Huse, 1997). Brammer and Pavelin (2008) linked between industry type and quality of environmental disclosure. Joshi et al. (2011) established a positive association between industry type (producing products) and environmental disclosure. Other types of industries do not disclose as much environmental information as per legitimacy theory and stakeholder theory. Since these industries are less sensitive to the environment, their social contact from an ethical viewpoint is less than environment-sensitive industries. Moreover, less polluting industries feel less pressure from the customers and other stakeholders. As a consequence, less environment-sensitive industries disclose less environmental information because of less demand from the stakeholders. Thus, this paper assumes that there exists a significant relationship between industry type and environmental disclosure.

H2: $\quad$ There is a significant impact of industry type on environmental disclosure.

\subsubsection{Profitability and Environmental Disclosure}

Usually, profitable firms disclose more environmental information than losing concerns (Said et al., 2009). Al-Tuwaijri et al. (2004) presented strong evidence in favour of a positive relationship between profit margin and environmental disclosure. On the contrary, Hackston and Milne (1996) argue that the 
profitability of a firm does not have any effect on environmental disclosures (Dibia \& Onwuchekwa 2015). According to legitimacy theory, a profitable company has more responsibility and accountability to the society because profitable companies want to sustain by saving the environment and serving society. Stakeholders' expectations are also higher from the profitable companies because stakeholders do not forgive a profitable company for mismanaging the environment. Therefore, it is assumed that profitability has a mixed impact on environmental disclosure.

H3: There is a significant impact of profitability on environmental disclosure.

\subsubsection{Leverage and Environmental Disclosure}

Leverage has no significant impact on firms' environmental disclosure (Dibia \& Onwuchekwa, 2015). Uyar, Kilic, and Bayyurt (2013) claimed that a firm's leverage is negatively associated with its environmental disclosure. Leverage depends on external debt financing, and the financial institution is a vital stakeholder. These institutions impose environmental safety dimensions for issuing loans and grants. Consequently, levered companies disclose more environmental information due to the regulations of financial institutions than non-levered companies. The managers following managerial branch of stakeholder theory would take into account powerful stakeholders' interests (Deegan \& Jeffry, 2006) while disclosing their social and environmental information. Accordingly, this study assumed that leverage has a mixed impact on its environmental disclosure level.

H4: There is a significant impact of firms' leverage on environmental disclosure.

Under these circumstances, this paper examines the impact of company characteristics on environmental disclosure since reporting in Bangladesh remains voluntary.

\section{Methodology}

The methodology section comprises three sections. The first section covers sample design, subsequently defining variables and formulation of the model and level of environmental disclosure.

\subsection{Sample Design}

Kothari (2004) stated that sampling is a plan to collect a sample from a population and refers to a systematic approach the researchers adopt in selecting units for the sample. In this connection, Quinlan, Babin, Carr, Griffin, and Zikmund (2011) emphasise on the target population. A target population comprises the composition of elements that holds the information objectively sought by the researcher and about which inferences are to be drawn (Malhotra $\&$ Carino, 2003). This paper seeks to identify the factors driving environmental performance of listed firms in Bangladesh. From probability sampling and nonprobability sampling techniques, this paper employs the non-probability technique by relying heavily on the researchers' judgement (Quinlan et al., 2011). Table-2 shows the distribution of the sample by industry. 
Excluding insurance and jute companies, the percentage of sample is approximately 29\%. Moreover, the listed number of Banking, textile and clothing, leasing and financing companies are 99, and the study considers 19 $(20 \%)$ companies from among 99 to present unbiased result. This study considered the annual reports of 2017 for the disclosure level, and it was conducted in the year 2018.

Table 2. Sector-wise sampling distribution

\begin{tabular}{lccccl}
\hline \multirow{2}{*}{ Industry Type } & \multicolumn{2}{c}{ Population } & \multicolumn{2}{c}{ Sample } & Sample to \\
\cline { 2 - 5 } & No. & $\%$ & No. & $\%$ & Population (\%) \\
\hline Bank & 30 & 10.2 & 10 & 14.29 & 33.33 \\
Insurance & 47 & 15.99 & - & - & - \\
Leasing and Finance & 23 & 7.82 & 3 & 4.29 & 13.04 \\
Textile and Clothing & 46 & 15.65 & 6 & 8.57 & 13.04 \\
Pharmaceuticals and Chemicals & 28 & 9.52 & 14 & 20.0 & 50.0 \\
Engineering and Electrical & 33 & 11.22 & 9 & 12.86 & 27.27 \\
Fuel and Energy & 18 & 6.12 & 4 & 5.71 & 22.22 \\
Foods and Allied & 18 & 6.12 & 3 & 4.29 & 13.04 \\
Cement & 7 & 2.38 & 4 & 5.71 & 57.14 \\
Ceramic & 5 & 1.7 & 4 & 5.71 & 80 \\
ICT & 7 & 2.38 & 2 & 2.86 & 28.57 \\
Leather and Footwear & 5 & 1.7 & 1 & 1.43 & 20 \\
Paper and Printing & 2 & .68 & 2 & 2.86 & 100 \\
Services and Property & 4 & 1.36 & 3 & 4.29 & 75 \\
Telecommunication & 2 & .68 & 1 & 1.43 & 50 \\
Jute & 3 & 1.02 & 0 & 0 & 0 \\
Travel and Leisure & 4 & 1.36 & 1 & 1.43 & 25 \\
Miscellaneous & 12 & 4.08 & 3 & 4.29 & 25 \\
Total & 294 & 100 & 70 & 100 & 23.80 \\
\hline
\end{tabular}

Source: Annual Reports of Dhaka Stock Exchange

\subsection{Defining Variables and Formulation of Model}

This study considers one dependent variable and four independent variables. Level of environmental disclosure (LED) is the dependent variable while size, profitability, leverage and industry type are the independent variables. The measuring scale of each variable is explained below in brief. Company size is characterised by sales volume in taka. The authors take the natural log of sales figure. Profitability is measured by return on asset $(R O A)$, which is a percentage of net profit after tax over total assets. Leverage ( $L E V)$ is measured by the debtequity ratio. This ratio shows the portion of debt capital in the total capital structure. Industry type (TYPE) is the dummy variable that categorises the production nature. This variable takes value 1 when it is a product and 0 when it is a service. To know the impact of firm specific factors on environmental disclosure level, the following model has been established.

$$
L E D=\beta_{0}+B_{1} S I Z E+B_{2} R O E+\beta_{3} L E V+B_{4} T Y P E+\varepsilon
$$

\subsection{Level of Environmental Disclosure}

The literature regarding the Bangladesh context measured disclosure levels of environmental information through content analysis from annual reports. Unlike 
content analysis, in this study, the quality of environmental information has been assessed. The quality of disclosure is ascertained from various parts of the annual report and scored into four (4) levels where the disclosure quality continuum advances from 'no disclosure on environmental performance' to 'very specific disclosure on performance'. It is noteworthy that quality of disclosure does not mean the volume or quantity of disclosures; rather quality means the value of information that bears relevance to the stakeholders' decision-making (Baalouch et al., 2019).This technique is supported by Wiseman (1982) where the score ranges between 0 and 3 where 3 is monetary information, 2 is concrete nonmonetary information, 1 is general nonmonetary information, and 0 is no information. Using monetary and nonmonetary environmental disclosure is an effective tool to gauge levels of corporate EID (Cho \& Patten, 2007). Content analysis is the most popularly applied technique in reporting research history. Generally, content analysis (quantify the volume of disclosure) is used to measure the environmental disclosure such as the number of words (Neu, Warsame, \& Pedwell, 1998), sentences (De Villiers \& Van Staden, 2011) or lines (Patten, 2002), and developed various disclosure indexes (Wiseman, 1982; Al-Tuwaijri et al., 2004) in order to estimate the nature and quality of disclosures.

According to Joseph \&Taplin (2011), there are two ways of applying content analysis technique. These mechanisms are disclosure occurrence and disclosure abundance method. The disclosure abundance method entails counting pages, words, or sentences on a checklist of disclosure items. The disadvantage of this method is that it can lead to double counting when a particular item on the checklist of disclosure items is counted twice or more because it occurs more than once in the actual report. Nevertheless, the most commonly used approach is an unweighted index which follows a dichotomous procedure in which an item scores one if it is disclosed, zero if it is not disclosed and NA if it is not applicable (Cooke, 1989; Ahmed \& Nicholls, 1994; Abdel Karim 1995; Leventis \& Weetman, 2004; Ghazali \& Weetman, 2006; Akhtaruddin, Hossain, Hossain, \& Yao, 2009; Hossain \&Hammami, 2009; Ahmed \&Dey, 2011;Adelopo, 2011; Uwuigbe \& Uadiale, 2011; Zubairu, Sakariyau, \& Dauda, 2011; Ienciu, 2012). Several researchers (Cooke, 1989; Naser \& Al-Khatib, 2000; Leventis \&Weetman 2004; Wang, Sewon, \& Claiborne, 2008) avoided weighted index arguing that it introduces additional subjectivity in scoring the disclosure items. In this study, Omar and Simon (2011) further argued that a large number of items in the index reduce the impact of weighting individual items differently. To avoid the limitations of abundance index and dichotomous procedure, we quantify environmental disclosure as general, partly specific and specific environmental information. This index will rate better and express real performance. Here we classified the disclosure content and its sources in the following manner.

According to Table-3, this study categorises the environmental disclosure into four. If there is no environmental disclosure made by a firm, this paper levelled it as ' 0 '. If any firm discloses general environmental information (policy, future programme etc.) in the 'Chairman Statement' of the annual report, this study coded it as ' 1 '. This paper has scored ' 2 ' when environmental information disseminated by a firm with minimal specification in 'Chairman Statement' like 'Tk. 50 lac is approved for ETP set up'. Firms which report stand-alone for 
environmental programmes as well as quantitative environmental information in 'Chairman Statement or Directors' Report' like 'Carbon emission reduced by $10 \%$ comparing to the previous year' are levelled as ' 3 '.

Table 3. Description and appearance of disclosure information

\begin{tabular}{cll}
\hline Level & Description & Appearance \\
\hline 0 & $\begin{array}{l}\text { No disclosure } \\
\text { General discussion on company policy, mission, } \\
\text { vision relating to the importance of environment } \\
\text { protection programmes for corporate houses that } \\
\text { appear in the chairman's statement }\end{array}$ & $\begin{array}{l}\text { None } \\
\text { Chairman's statement }\end{array}$ \\
2 & $\begin{array}{l}\text { General discussion with little specifications about } \\
\text { the environmental programmes to be taken in } \\
\text { future that appear in the chairman's statement }\end{array}$ & Chairman's statement \\
3 & $\begin{array}{l}\text { Specific discussion with quantitative information } \\
\text { about various programmes already implemented } \\
\text { and programmes to be implemented }\end{array}$ & $\begin{array}{l}\text { Chairman's statement and } \\
\text { separate report on environment } \\
\text { and society }\end{array}$ \\
\hline
\end{tabular}

\subsection{Reliability and Validity of Research Instruments}

Marston and Shrives (1991) argue that the disclosure index is a valid empirical method for collecting data and measuring information content in a company's annual reports. Similarly, Gray, McSweeney, and Shaw (1984) demonstrate that scoring annual reports using the disclosure index offers valuable insights into the level of particular disclosures. Hackston and Milne (1996) advocate for the appropriateness of disclosure index in statistical analysis and affirm that it does not reduce the effectiveness of regression results. The critical aspect of the coding instrument used in this study is the inclusion of appropriate disclosure items. To ensure the accuracy of these lists, the researchers carefully studied the source documents that mandated the disclosure items and prior relevant research and repeated the process until the confidence over the issue is attained. The checklists were sent to two professors of accounting with research experience in the field and two practising chartered accountants to examine the correctness of the lists. After receiving their feedback, any disagreement regarding any disclosure item is consulted and rechecked. All annual reports were reviewed thoroughly, and the websites of the sample companies were visited twice in order to affirm the reliability of the disclosure index. The second examination is made after assessing all the annual reports and websites in the first round to ensure objective results. The reliability of the coding instruments is further supported by several earlier studies (Akhtaruddin, 2005; Çürük, 2009; Leventis \& Weetman, 2004; Rouf, 2010).

\section{Results and Analysis}

The results of descriptive statistics and regression analysis have been discussed in the following parts. Based on ordinary least square (OLS), we have estimated the results.

\subsection{Overall Disclosure Level}

A general representation of all the companies in the dataset is presented in Table-4. "No disclosure companies" scored highest in frequencies, and 
companies with specific and quantitative disclosures comprise only $15.7 \%$ of the sample, and environmental disclosure by any means is $67.1 \%$.

Table 4. Case Summary

\begin{tabular}{lcc}
\hline Level of environmental disclosure (LED) & N & Marginal (\%) \\
\hline No Disclosure & 24 & 32.9 \\
General Discussion & 16 & 22.9 \\
General Discussion with Little Specifications & 21 & 28.6 \\
Specific Discussion with Quantitative Information & 11 & 15.7 \\
Total & 72 & 100.0 \\
\hline
\end{tabular}

Table 5. Sector-wise Environmental Disclosure

\begin{tabular}{|c|c|c|c|c|c|c|}
\hline & & $L E D-3$ & LED-2 & LED-1 & $L E D-0$ & Total \\
\hline $\begin{array}{l}\text { Pharmaceuticals } \\
\text { and Chemicals }\end{array}$ & Sector-1 & $3(13 \%)$ & $1(6 \%)$ & $2(14 \%)$ & $1(4 \%)$ & 7 \\
\hline Banks & Sector-2 & $5(22 \%)$ & $2(13 \%)$ & $1(7 \%)$ & $2(9 \%)$ & 10 \\
\hline $\begin{array}{l}\text { Telecom, IT, } \\
\text { Services and } \\
\text { Property, } \\
\text { Miscellaneous, } \\
\text { Travel and } \\
\text { Leisure }\end{array}$ & Sector-3 & $2(9 \%)$ & - & - & $3(14 \%)$ & 5 \\
\hline $\begin{array}{l}\text { Cement, Paper } \\
\text { and Printing, } \\
\text { Fuel and Power, } \\
\text { Food and allied, } \\
\text { Ceramic }\end{array}$ & Sector- 4 & $5(22 \%)$ & $3(20 \%)$ & $3(21 \%)$ & $7(33 \%)$ & 18 \\
\hline Tannery & Sector-5 & - & - & $1(7 \%)$ & - & 1 \\
\hline Engineering & Sector-6 & $3(13 \%)$ & $8(53 \%)$ & $6(43 \%)$ & $5(24 \%)$ & 22 \\
\hline Textile & Sector-7 & $3(13 \%)$ & $1(6 \%)$ & $1(7 \%)$ & $1(4 \%)$ & 6 \\
\hline $\begin{array}{l}\text { Leasing and } \\
\text { Finance }\end{array}$ & Sector-8 & $1(4 \%)$ & - & - & $2(9 \%)$ & 3 \\
\hline Total & & $22(29.17 \%)$ & $15(20.83 \%)$ & $14(19.44 \%)$ & $21(29 \%)$ & 72 \\
\hline
\end{tabular}

Out of 21 level-0 firms, seven firms from the cement, paper and printing, fuel and power, food and allied, and ceramic industry did not disclose anything.One firm from the pharmaceutical and chemical sector, two firms from the banking sector, five firms from the engineering sector, one firm from the textile sector, two firms from the leasing and finance sector, and three firms from telecom, IT, services and property, miscellaneous, travel and leisure did not disclose any information concerning the environment.

The environmental disclosure level highlights that non-manufacturing companies disclose more than others, specifically financial institutions disclose more information. This is because of robust regulatory supervision by the Bangladesh Bank over the banking sector. Bangladesh Bank also established environmental regulation and encouraged listed banks to give loans to environment-friendly projects. Moreover, the structure of the banking sector is more sophisticated and well-governed. Stakeholders in the banking sectors are spread over the country and more sensitive to this kind of issue. Again, banks deal with data, and it is easy to produce quantitative information. In Bangladesh, banking is very competitive, and any non-compliance often results in the loss of 
the customers' faith. Since banking depends on customers' faith, this sector discloses as much as information as possible.

The ROE does not significantly affect the LED. It means firms' profitability does not affect the disclosure levels significantly. Similarly, the industry type (product-1, service-0) does not have any significant impact on disclosure practices. On the other hand, leverage and size have a significant positive impact on disclosure level. Therefore, from the legitimacy theory perspective, large firms (high sales) disclose more environmental information to legitimise their activities. From individual disclosure level, we find that size has a significant positive impact on disclosure level (LED-1, LED-2, LED-3). The same conclusion can be drawn that larger firms tend to disclose more environmental information. Performance has a significant positive impact on LED-3. Firms with high performance disclose quantitative information about various programmes already implemented and programmes to be implemented. This aligns with the legitimacy theory. Highly performed and large firms tend to disclose more environment-related information. The results are provided in Table-6.

Table 6. Regression Results

\begin{tabular}{lllll}
\hline & $L E D$ & $L E D-1$ & $L E D-2$ & LED-3 \\
\hline Intercept & $160.94^{* * *}$ & $-9.29^{*}$ & $-10.17^{* *}$ & $-15.03^{* *}$ \\
& $(.00)$ & $(.07)$ & $(.04)$ & $(.02)$ \\
SIZE & $167.89^{* *}$ & $.93^{*}$ & $1.08^{* *}$ & $1.374^{* *}$ \\
& $(.02)$ & $(.09)$ & $(.04)$ & $(.03)$ \\
ROE & 166.68 & .01 & .025 & $.079^{* *}$ \\
& $(.13)$ & $(.88)$ & $(.47)$ & $(.04)$ \\
LEV & $172.05^{* *}$ & .18 & -.477 & .134 \\
& $(.01)$ & $(.32)$ & $(.34)$ & $(.52)$ \\
TYPE & 161.53 & .31 & -.038 & .701 \\
& $(.89)$ & $(.72)$ & $(.96)$ & $(.51)$ \\
\hline
\end{tabular}

***Significant at $1 \%$ level, ${ }^{* *}$ Significant at $5 \%$ level, and ${ }^{*}$ Significant at $1 \%$ level. Value in parenthesis represents $p$-value.

\section{Discussion}

We find that size has a statistically significant impact on disclosure level-1, as evident from the regression results. It has also a significant impact on level-2 and level-3 disclosure. These results support the first hypothesis and outline that the level of environmental disclosure is greater for large firms. The result is in line with the results of the literature and legitimacy theory. Firm size is measured by taking a natural log of total sales. The findings demonstrate that larger firms establish some company-wide environmental policies, practices and initiatives to overcome environmental degradation. They are more definitive and specific than small firms in planning and implementing environmental protection programmes which are supported by a strong financial status.

Profitability has an insignificant impact on disclosure level1 and level2. However, profitability significantly and positively affects disclosure level 3 . It means that when profitability increases, disclosure level-3 will also increase. So, the hypothesis is accepted in the case of level3 disclosure, but is rejected considering disclosure levels1 and 2. Firms with superior financial performance would have the intentions to convey their 'type' by taking initiatives and making 
higher and more objective environmental disclosures (Al-Tuwaijri et al., 2004; Clarkson, Overell, \& Chapple, 2011).These firms take more risks to deploy more funds for accomplishing the environmental protection agenda.

Parsons and Titman (2008) found that leverage and firm strategy are related, and the firms' long-term strategy should be consistent with the capital structure (Andrews, 1980; Barton \& Gordon, 1987). This paper finds that leverage has an insignificant impact on environment disclosure, taking into account level-1, level-2, and level-3. However, the impact is statistically significant, considering gross disclosure level (LED). This paper confirms the findings of Smith, Yahya, \& Amiruddin (2007) who found that leverage has an insignificant impact on separate disclosure levels. It reveals that capital structure does not signal environmental disclosures under individual disclosure level of the listed companies in Bangladesh. However, the relationship (positive and/or negative) discloses that a highly levered firm may tend to show its type by expressing their responsibilities to the society in annual reports to attract potential stakeholders (Ullmann, 1985). On the other hand, highly levered firms (higher risk) should be associated with high cash outlay and for that reason it may not be feasible to spend more on environmental protection programmes.

Another predictor variable is industry categorisation. Production-based companies include tanneries, chemicals, paper, cement, fuel and power, food, engineering, ceramic and textile industries. Service industries include bank, telecom, travel and leisure, IT, leasing and finance, services and property. We incorporate dummy variable (TYPE) in our regression model. From the analysis, the categorisation is not significant in describing the environmental performance, which means that production or service-based industries do not differ in reporting environmental performances.

\section{Conclusion}

This study sought to ascertain the quality of environmental reporting as per company characteristics such as size, profitability, and leverage and industry type through the lens of legitimacy theory and stakeholder theory. Studies regarding environmental reporting of Bangladeshi companies show only the descriptive statistics of disclosures (see the literature review section). Some studies describe the nature of environmental information. Others find the reasons for non-disclosure at a standard level.

Studies also support that the quantity of environmental disclosures is increasing day by day (see the previous work section). However, the quality of environmental information varies as reporting is voluntary. Nevertheless, some perform high levels of environmental reporting. This study analysed which types of firms disclose more environmental information and what kind of information it is.

In this study, the environmental information is categorised into three: 'general discussion', 'discussion with little specifications' and 'specific goals'. The result shows that only $15.7 \%$ of firms disclose environmental information with a specific goal or target. Moreover, the study confirms that nonmanufacturing companies disclose more environmental information than 
manufacturing companies. The banking and paper, cement, fuel sectors disclose more specific information.

We observed that size is a crucial factor in the case of disclosure with little specifications and specific disclosure, whereas it has no impact on general information disclosures. Another important finding is that profitable companies disclose more specific information, but profitability does not have any association in the case of general information and little specific information disclosure. In this study, the impact of leverage on environmental performance is positive in the case of general information and specific information disclosure, but negative when disclosure with little specification though it is not a significant predictor of environmental disclosure. Finally, this study confirms that industry type (manufacturing and service industry) has no impact on environmental disclosures.

This paper provides insights into the quality of environmental disclosure of Bangladeshi companies. The results show that company features do not influence the general environmental information disclosure, but company size, profitability and capital structure have a significant impact on quality environmental disclosures. This implies that a large profitable company uses this voluntary disclosure to attract environment-sensitive consumers and to gain a competitive advantage over its competitors. On the contrary, regulatory agencies fail to implement environmental rules and policies, and other stakeholders are not so curious about environmental awareness. Thus, a specific characterised company discloses specific environmental information and enjoys benefits over others. The result may differ if non-listed manufacturing and service industries are taken into consideration. Nevertheless, the findings can be used in similar socio-economic and cultural conditions.

\section{References}

Abdel Karim, R.A. (1995).The nature and rationale of a conceptual framework for financial reporting by Islamic banks. Accounting and Business Research, 25(100), 285300.https://doi.org/10.1080/00014788.1995.9729916

Adams, C.A., Hill, W., \& Roberts, C.B. (1998). Corporate social reporting practices in western europe: legitimating corporate behavior. The British Accounting Review, 30(1), 121.https:// doi.org/10.1006/bare.1997.0060

Adelopo, I. (2011). Voluntary disclosure practices amongst listed companies in Nigeria. Advances in Accounting, 27(2), 338-345.https:// doi.org/10.1016/j.adiac.2011.08.009

Ahmad, A. (2012). Environmental accounting and reporting practices: significance and issues: a case from Bangladeshi companies. Global Journal of Management and Business Research, 12(14), 119-127.

Ahmed, A.A.A., \& Dey, M.M. (2011). Accounting disclosure scenario: an empirical study of the banking sector of Bangladesh. International Journal of Accounting and Management Information, 19(2). https:/ / doi.org/10.1108/ijaim.2011.36619baa.027.

Ahmed, K., \& Nicholls, D. (1994). The impact of non-financial company characteristics on mandatory disclosure compliance in developing countries: The case of Bangladesh. The International Journal of Accounting, 29, 62-77.

Akbas, H.E. (2014). Company characteristics and environmental disclosure: an empirical investigation on companies listed on Borsa Istanbul 100 index. Muhasebeve Finansman Dergisi, 62, 145-164.

Akhtaruddin, M. (2005). Corporate mandatory disclosure practices in Bangladesh. The International Journal of Accounting, 40(4), 399-422. 
Akhtaruddin, M., Hossain, M.A., Hossain, M.S., \& Yao, L. (2009). Corporate governance and voluntary disclosure in corporate annual reports of Malaysian listed firms. Journal of Applied Management Accounting Research, 7(1), 1-20.

Al-Gamrh, B.A., \& AL-Dhamari, R.A. (2016). Firm characteristics and corporate social responsibility disclosure. International Business Management, 10(18), 4283-4291.

Al-Tuwaijri, S.A., Christensen, T.E., \& Hughes, I.K. (2004). The relations among environmental disclosure, environmental performance, and economic performance: a simultaneous equations approach. Accounting, Organisations and Society, 29(5-6), 447-471. https://doi.org/10.1016/S0361-3682(03)00032-1

Andrews, K.R. (1980). Directors' responsibility for corporate strategy. Harvard Business Review, 30.

Archel, P., Husillos, J., Larrinaga, C., \& Spence, C. (2009). Social disclosure, legitimacy theory and the role of the state. Accounting, Auditing and Accountability Journal, 22(8), 1284-1307. https://doi.org/10.1108/09513570910999319

Arussi, A.S.A., Selamat, MH, \&Hanefah, M.M. (2009). Determinants of financial and environmental disclosures through the internet by Malaysian companies. Asian Review of Accounting, 17(1), 59-76. https:// doi.org/10.1108/13217340910956513

Baalouch, F., Ayadi, S.D., \&Hussainey, K. (2019). A study of the determinants of environmental disclosure quality: evidence from French listed companies.Journal of Management and Governance, 23, 939-971. https:/ / doi.org/10.1007/s10997-019-09474-0

Bansal, P.,\&Clelland, I. (2004). Talking trash: legitimacy, impression management, and unsystematic risk in the context of natural environment. The Academy of Management Journal, 47(1), 93-103. https:// doi.org/10.2307/20159562

Barton, S.L., \& Gordon, P. I. (1987). Corporate strategy: useful perspective for the study of capital structure? Academy of Management Review, 12(1), 6775.https:// doi.org/10.5465/amr.1987.4306479

Belal, AR (1997). Green reporting practices in Bangladesh. The Bangladesh Accountant, 25(1), 107115.

Belal, AR (2000). Environmental reporting in developing countries: empirical evidence from Bangladesh. Eco-Management and Auditing, 7(3),114-121.https://doi.org/10.1002/10990925(200009)7:3<114::AID-EMA131>3.0.CO;2-E

Bose, S. (2012). Environmental accounting and reporting in fossil fuel sector: a study on Bangladesh oil, gas and mineral corporation (Petrobangla). The Cost and Management, 34(2), 53-67.

Brammer, S., \& Pavelin, S. (2008). Factors influencing the quality of corporate environmental

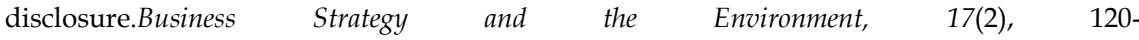
136.https:// doi.org/10.1002/bse.506

Brown, N., \& Deegan, C.M. (1998). The public disclosure of environmental performance information - A dual test of media agenda setting theory and legitimacy theory. Accounting and Business Research, 29(1), 21-41.https://doi.org/10.1080/00014788.1998.9729564

Burlea, S.A. \&Popa I. (2013). Legitimacy theory. In: SO. Idowu, N. Capaldi, L. Zu, and A.D. Gupta (eds), Encyclopedia of Corporate Social Responsibility (pp. 1579-1584). Berlin, Heidelberg: Springer-Verlag.

Cho, C.H., \& Patten, D.M. (2007). The role of environmental disclosures as tools of legitimacy: A research note. Accounting, Organisations and Society, 32(7-8), 639647.https://doi.org/10.1016/j.aos.2006.09.009

Clarkson, M.B.E. (1995). A Stakeholder Framework for Analysing and Evaluating Corporate Social Performance. Academy of Management Review, 20 (1), 92 117.https:// doi.org/10.2307/25888

Clarkson, P.M., Li, Y., Richardson, G. D., \&Vasvari, F. P. (2008). Revisiting the relation between environmental performance and environmental disclosure: An empirical analysis. Accounting, Organisations $\quad$ and $303-$ 327.https:// doi.org/10.1016/j.aos.2007.05.003

Clarkson, P.M., Overell, M.B., \& Chapple, L. (2011). Environmental reporting and its relation to corporate environmental performance. Abacus, 47(1), 27-60.https://doi.org/10.1111/j.14676281.2011.00330.x 
Cooke, T.E. (1989). Disclosure in the corporate annual reports of Swedish companies.Accounting and Business Research, 19(74),113-124.https://doi.org/10.1080/00014788.1989.9728841

Cormier, D., Magnan, M., \& Van Velthoven, B. (2005). Environmental disclosure quality in large German companies: economic incentives, public pressures or institutional conditions? European Accounting Review, 14(1), 3-39.https:// doi.org/10.1080/0963818042000339617

Cowen, S.S., Ferreri, L.B., \& Parker, L.D. (1987). The impact of corporate characteristics on social responsibility disclosure: A typology and frequency-based analysis. Accounting, Organisations and Society, 12(2), 111-122.https:// doi.org/10.1016/0361-3682(87)90001-8

Çürük, T. (2009). An analysis of the companies' compliance with the EU disclosure requirements and corporate characteristics influencing it: A case study of Turkey. Critical Perspectives on Accounting, 20(5), 635-650.https://doi.org/10.1016/j.cpa.2007.05.003

De Villiers, C., \& Van Staden, CJ (2010). Shareholders' requirements for corporate environmental disclosures: a cross country comparison. The British Accounting Review, 42(4), 227-240.https://doi.org/10.1016/j.bar.2010.08.002

Deegan, C. (2004). Environmental disclosures and share prices-a discussion about efforts to study this relationship. Paper presented at the Accounting Forum.

Deegan, C. (2007). Organisational legitimacy as a motive for sustainability reporting. In: J. Unerman, B. O'Dwyer, and J. Bebbington (eds), Sustainability Accounting and Accountability (pp. 127-149). London: Routledge.

Deegan, C., \& Gordon, B. (1996). A study of the environmental disclosure practices of Australian corporations. Accounting and Business Research, 26(3), 187-199. https://doi.org/10.1080/00014788.1996.9729510

Deegan, C., \& Rankin, M. (1996). Do Australian companies report environmental news objectively? an analysis of environmental disclosures by firms prosecuted successfully by the environmental protection authority. Accounting, Auditing and Accountability Journal, 9(2), 50-67.https://doi.org/10.1108/09513579610116358

Deegan, C., Cooper, B.J., \& Shelly, M. (2006). An investigation of TBL report assurance statements: UK and European evidence. Managerial Auditing Journal, 21(4), 329371.https:// doi.org/10.1108/02686900610661388

Deegan, C. \& Jeffry, U. (2006). Financial accounting theory. Berkshire SL6 2QL, McGraw-Hill Education.

Deegan, C., Rankin, M., and Tobin, J. (2002). An examination of the corporate social and environmental disclosures of BHP from 1983-1997: A test of legitimacy theory. Accounting, Auditing accountability Journal, 15(3), 31243.https:// doi.org/10.1108/09513570210435861

Delmas, M.A. (2002). Innovating against European rigidities: Institutional environment and dynamic capabilities. The Journal of High Technology Management Research, 13(1),19-43. https://doi.org/10.1016/S1047-8310(01)00047-5

Dias-Sardinha, I., Reijnders, L., \& Antunes, P. (2007). Developing sustainability balanced scorecards for environmental services: A study of three large Portuguese companies. Environmental Quality Management, 16(4), 13-34.https://doi.org/10.1002/tqem.20139

Dibia, N.O., \& Onwuchekwa, J.C. (2015). Determinants of environmental disclosures in Nigeria: A case study of oil and gas companies. International Journal of Finance and Accounting, 4(3), 145-152.https://doi.org/10.5923/j.ijfa.20150403.01

Ebiringa, O., Yadirichukwu, E., Chigbu, E., \& Ogochukwu, O.J. (2013). Effect of firm size and profitability on corporate social disclosures: the Nigerian oil and gas sector in focus. British Journal of Economics, Management and Trade, 3(4), 563574.https://doi.org/10.9734/BJEMT/2013/5147

Eljayash, K.M., James, K., \& Kong, E. (2012). The quantity and quality of environmental disclosure in annual reports of national oil and gas companies in Middle East and North Africa. International Journal of Economics and Finance,4(10), 201217.https://doi.org/10.5539/ijef.v4n10p201

Elmagrhi, M.H., Ntim, C.G., Elamer, A.A., \& Zhang, Q. (2019). A study of environmental policies and regulations, governance structures, and environmental performance: The role of female directors. Business Strategy and the Environment, 28(1), 206220.https:// doi.org/10.1002/bse.2250 
Freeman, R. E., Harrison, J. S., \& Wicks, A. C. (2007). Managing for stakeholders: survival, reputation, and success. Yale University Press.

Frost, G.R. (2007). The introduction of mandatory environmental reporting guidelines: Australian evidence. Abacus, 43(2), 190-216. https://doi.org/10.1111/j.14676281.2007.00225.x

Gani, A. \& Sharma, B. (2009). The effect of the business environment on pollution. The Berkeley Electronic Press, Beijing, China.

Ghazali, N.A.M., \& Weetman, P. (2006). Perpetuating traditional influences: Voluntary disclosure in Malaysia following the economic crisis. Journal of International Accounting, Auditing and Taxation, 15(2), 226-248.https://doi.org/10.1016/j.intaccaudtax.2006.08.001

Gray, S.J., McSweeney, L., \& Shaw, J.C. (1984). Information disclosure and the multinational corporation. John Wiley \& Sons.

Hackston, D., \& Milne, M.J. (1996). Some determinants of social and environmental disclosures in New Zealand companies. Accounting, Auditing and Accountability Journal, 9(1), 77108.https:/ / doi.org/10.1108/09513579610109987

Halme, M., \& Huse, M. (1997). The influence of corporate governance, industry and country factors on environmental reporting. Scandinavian Journal of Management, 13(2), 137157.https://doi.org/10.1016/S0956-5221(97)00002-X

Hasseldine, J., Salama, A., \& Toms, S. (2005). Quantity Versus Quality: The Impact of Environmental Disclosures on the Reputations of UK PLCs. The British Accounting Review, 37(2), 231-248. https://doi.org/10.1016/j.bar.2004.10.003.

Holt, D. (1998). The perceived benefits of an environmental management standard. Business Process Management Journal, 4(3), 204-213.https:/ / doi.org/10.1108/14637159810224313

Hossain, M., Islam, K., \& Andrew, J. (2006). Corporate social and environmental disclosure in developing countries: evidence from Bangladesh.Proceedings of the Asian Pacific Conference on International Accounting Issues, Hawaii.

Hossan, M.M. (2014). Evolution of environmental policies in Bangladesh (1972-2010). Journal of the Asiatic Society of Bangladesh (Hum.), 59(1), 39-63.

Iatridis, G.E. (2013). Environmental disclosure quality: Evidence on environmental performance, corporate governance and value relevance. Emerging Markets Review,14, 5575.https:// doi.org/10.1016/j.ememar.2012.11.003

Ienciu, I.A. (2012). The relationship between environmental reporting and corporate governance characteristics of Romanian listed entities. Accounting and Management Information Systems, 11(2), 267-294.

Imam, S. (2000). Corporate social performance reporting in Bangladesh. Managerial Auditing Journal, 15(3), 133-142. https:/ / doi.org/10.1108/02686900010319384

Islam, M.A., and Deegan, C. (2008). Motivations for an organisation within a developing country to report social responsibility information. Accounting, Auditing and Accountability Journal, 21(6), 850-874.https:// doi.org/10.1108/09513570810893272

Jariya, A.I. (2015). Environmental disclosures in annual reports of Sri Lankan corporate: a content analysis. Journal of Emerging Trends in Economics and Management Sciences, 6(8), 350357.

Joseph, C. \&Taplin, R. (2011). The measurement of sustainability disclosure: Abundance versus occurrence. Accounting Forum, 35(1), 19-31. https://doi.org/10.1016/j.accfor.2010.11.002.

Joshi, P.L., Suwaidan, M.S., \& Kumar, R. (2011). Determinants of environmental disclosures by Indian industrial listed companies: empirical Study. International Journal of Accounting and Finance, 3(2), 109-130. https:// doi.org/10.1504/IJAF.2011.043843

Kolk, A. (2006). Sustainability, accountability and corporate governance: exploring multinationals' reporting practices. Business Strategy and the Environment, 17(1), 115.https:// doi.org/10.1002/bse.511

Kothari, C.R. (2004). Research methodology: Methods and techniques (2nd ed.). New Delhi, India: New Age International Publisher.

Lada, M., \& Kozarkiewicz, A. (2013). Teorialegitymizacji w badaniach z zakresurachunkowo Ăci. Zeszyty Teoretyczne Rachunkowo Ăci, 71(127), 161-175. 
Leventis, S., \& Weetman, P. (2004). Voluntary disclosures in an emerging capital market: some evidence from the Athens Stock Exchange. Advances in International Accounting, 17, 227-250. https://doi.org/10.1016/S0897-3660(04)17011-6

Li, D., Huang, M., Ren, S., Chen, X., \& Ning, L. (2018). Environmental legitimacy, green innovation, and corporate carbon disclosure: Evidence from CDP China 100. Journal of Business Ethics, 150(4), 1089-1104. https://doi.org/10.1007/s10551-016-3187-6

Li, Y., Richardson, G.D., \& Thornton, D.B. (1997). Corporate disclosure of environmental liability information: theory and evidence. Contemporary Accounting Research, 14(3), 435474.https://doi.org/10.1111/j.1911-3846.1997.tb00535.x

Majumder, M.T.H., Li, X., Akter, A., \& Begum, M. (2019). Corporate attributes and corporate social disclosures: a meta-analytical review. International Journal of Law and Management, 61(1), 45-72. https://doi.org/10.1108/IJLMA-02-2018-0023

Malhotra, V.M., \& Carino, N.J. (2003). Handbook on nondestructive testing of concrete (2nd ed.). Florida, USA: CRC press.

Marshall, S., Brown, D., \& Plumlee, M. (2007). 'Negotiated' transparency? Corporate citizenship engagement and environmental disclosure. Journal of Corporate Citizenship, 28, 43-60.

Marston, C.L., \& Shrives, P. J. (1991). The use of disclosure indices in accounting research: a review article. The British Accounting Review, 23(3), 195-210. https://doi.org/10.1016/08908389(91)90080-L

Mashayekhi, B., \& Mashayekh, S. (2008). Development of accounting in Iran. The International Journal of Accounting, 43(1), 66-86. https:// doi.org/10.1016/j.intacc.2008.01.004

McGuinness, P.B., Vieito, J.P., \& Wang, M. (2017). The role of board gender and foreign ownership in the CSR performance of Chinese listed firms. Journal of Corporate Finance,42, 75-99.https:// doi.org/10.1016/j.jcorpfin.2016.11.001.

Michelon, G., \&Parbonetti, A. (2012). The effect of corporate governance on sustainability disclosure. Journal of Management and Governance, 16(3), 477509.https:// doi.org/10.1007/s10997-010-9160-3

Michelon, G., Pilonato, S., \& Ricceri, F. (2015). CSR reporting practices and the quality of disclosure: An empirical Analysis. Critical Perspectives on Accounting, 33, 5978.https:// doi.org/10.1016/j.cpa.2014.10.003.

Mitali, S., Kuhali, M., \& Pattanayak, J. K. (2000). Corporate environmental disclosure practices in India. Journal of Applied Accounting Research, 12(2), 139156.https://doi.org/10.1108/09675421111160709

Naser, K., \& Al-Khatib, K. (2000). The extent of voluntary disclosure in the board of directors statement: the case of Jordan. Advances in International Accounting, 13, 99-118.

Neu, D., Warsame, H., and Pedwell, K. (1998). Managing public impressions: environmental disclosures in annual reports. Accounting, Organisations and Society, 23(3), 265282.https:// doi.org/10.1016/S0361-3682(97)00008-1

Noman, A.A., \&Akter, N. (2010). Human rights approach to environment protection: a Bangladesh study. The Chittagong University Journal of Law, 15(1), 71-85.

O'Donovan, G. (2002). Environmental disclosures in the annual report: Extending the applicability and predictive power of legitimacy theory. Accounting, Auditing and Accountability Journal, 15(3), 344-371. https:// doi.org/10.1108/09513570210435870

Parsons, C., \& Titman, S. (2008). Handbook of corporate finance: empirical corporate finance, capital structure and corporate strategy. Amsterdam,Netherlands:Elsevier.

Patel, S.A., Balic, A., \& Bwakira, L. (2002). Measuring transparency and disclosure at firm-level in emerging markets. Emerging Markets Review, 3(4), 325337.https:// doi.org/10.1016/S1566-0141(02)00040-7

Patten, D.M. (1991). Exposure, legitimacy and social disclosure. Journal of Accounting and Public Policy, 10(4), 297-308. https://doi.org/10.1016/0278-4254(91)90003-3

Quinlan, C., Babin, B.J., Carr, J., Griffin, M., \&Zikmund, W.G. (2011). Business research methods: Hampshire,UK: South-Western Cengage Learning Andover.

Rahman, M.A., \& Muttakin, M.B. (2005). Corporate environmental reporting practices in Bangladesh-a study of some selected companies. The Cost and Management, 33(4), 13-21.

Rouf, D. (2010). Voluntary Disclosure Practice of Pharmaceutical and Chemical Companies: Evidence from Bangladesh. Journal of World Vision, 3, 83-96. 
Said, R., Zainuddin, YH, \& Haron, H. (2009). The relationship between corporate social responsibility disclosure and corporate governance characteristics in Malaysian public listed $\begin{array}{llll}\text { companies. Social Responsibility } & \text { 212-226. }\end{array}$ https://doi.org/10.1108/17471110910964496.

Salama, A., Anderson, K.P., \&Toms, S. (2011). Does community and environmental responsibility affect firm risk: evidence from UK panel data 1994-2006. Business Ethics: A European Review, 20, 192-204. https:// doi.org/10.1111/j.1467-8608.2011.01617.x

Schipper, K. (1991). Commentary on analysts' forecast. Accounting Horizons, 5(4), 105-121.

Setyorini, C.T., \& Ishak, Z. (2012). Corporate social and environmental disclosure: a positive accounting theory view point. International Journal of Business and Social Science, 3(9), 152-164.

Shil, N.C., \& Iqbal, M. (2005). Environmental disclosure-a Bangladesh perspective.The Cost and Management, 3, 85-93.

Simnett, R., Vanstraelen, A., \& Chua, W.F. (2009). Assurance on sustainability reports: An international comparison. The Accounting Review, 84(3), 937967.https://doi.org/10.2308/accr.2009.84.3.937

Sinclair-Desgagné, B. \& Gozlan (2003). A theory of environmental risk disclosure. Journal of Environmental Economics and Management, 45(2), 377-393. https://doi.org/10.1016/S00950696(02)00056-6

Smith, M., Yahya, K., \& Amiruddin, A.M. (2007). Environmental disclosure and performance reporting in Malaysia. Asian Review of Accounting, 15(2), 185199.https:// doi.org/10.1108/13217340710823387

Sobhani, F.A., Amran, A., \& Zainuddin, Y. (2012). Sustainability disclosure in annual reports and websites: a study of the banking industry in Bangladesh. Journal of Cleaner Production, 23(1), 75-85. https://doi.org/10.1016/j.jclepro.2011.09.023

Sobhani, F.A., Amran, A., \& Zainuddin, Y. (2009). Revisiting the practices of corporate social and environmental disclosure in Bangladesh. Corporate Social Responsibility and Environmental Management, 16(3),167-183. https://doi.org/10.1002/csr.193

Suchman, M.C. (1995). Managing legitimacy: Strategic and institutional approaches. Academy of Management Journal, 20(3), 571-610. https:// doi.org/10.2307/258788

Ullmann, A.A. (1985). Data in search of a theory: A critical examination of the relationships among social performance, social disclosure, and economic performance of US firms. Academy of Management Review, 10(3), 540-557. https:/ / doi.org/10.5465/AMR.1985.4278989

Uwuigbe, U., \& Uadiale, O. (2011). Intellectual capital and business performance: evidence from Nigeria. Interdisciplinary Journal of Research in Business, 1, 49-56.

Uyar, A., Kilic, M., \&Bayyurt, N. (2013). Association between firm characteristics and corporate voluntary disclosure: Evidence from Turkish listed companies. Intangible Capital, 9(4), 10801112. https:// doi.org/10.3926/ic.439

Verrecchia, RE (1983). Discretionary disclosure. Journal of Accounting and Economics, 5, 179-194. https:// doi.org/10.1016/0165-4101(83)90011-3

Wang, K., Sewon, O., \& Claiborne, M.C. (2008). Determinants and consequences of voluntary disclosure in an emerging market: Evidence from China. Journal of International Accounting, Auditing and Taxation, 17(1), 14-30. https://doi.org/10.1016/j.intaccaudtax.2008.01.001

Wilmshurst, T.D. \& Frost, G.R. (2000). Corporate environmental reporting: A test of legitimacy theory. Accounting, Auditing, and Accountability Journal, 13(1), 10 26.https:// doi.org/10.1108/09513570010316126

Wiseman, J. (1982). An evaluation of environmental disclosures made in corporate annual reports. Accounting, Organisations and Society, 7(1), 53-63. https://doi.org/10.1016/03613682(82)90025-3

Zeng, S., Xu, X., Dong, Z., \& Tam, V. W. (2010). Towards corporate environmental information disclosure: an empirical study in China. Journal of Cleaner Production, 18(12), 1142 1148.https:// doi.org/10.1016/j.jclepro.2010.04.005

Zubairu, U.M., Sakariyau, O.B., \& Dauda, C.K. (2011). Social reporting practices of Islamic banks in Saudi Arabia. International Journal of Business and Social Science, 2(23), 193-205. 